\title{
Tema: O RETORNO DO ENSINO DE FILOSOFIA AO SEGUNDO GRAU.
}

1 - No seu entender, qual o significado
da volta da Filosofia no segundo
grau? O senhor atribui esse projeto
ao peculiar contexto sócio-político-
econômico que o País está
atravessando?

R - Não cremos que a tentativa de se fazer retornar a filosofia ao segundo grau deva-se apenas ao nosso peculiar contexto sócio-político-econômico do momento. Embora de forma modesta, a filosofia lançou algumas raízes na nossa cultura, desde os tempos da Colônia, e a necessidade de introduzí-la na escola secundária fez-se sentir muito cedo. Na Constituinte de 1823 , houve um projeto criando um curso superior de filosofia, rejeitado em favor de um outro que ordenava a fundação de uma Faculdade de Ciências Jurídicas. Os deputados da época entenderam que o Brasil carecia mais de advogados do que de filósofos, mas a filosofia instalou-se, desde a primeira metade do século XIX, como disciplina importante no célebre Colégio D. Pedro II. Somente em príncipios do nosso século, é que a filosofia vai ao ensino superior, com a criação da Faculdade de S. Bento, em 1908. Eu diria, porém que, já no Império, o educador brasileiro sempre entendeu a necessidade de uma área de reflexão fundamental no colégio secundário. $\mathrm{O}$ papel extremamente formador desse tipo de reflexão sempre foi ressaltado, entre nós.

\section{NELSON GONÇALVES GOMES*}

Basta vermos, como sinal disso, que a cadeira de filosofia do citado Colégio D. Pedro II foi disputada por algumas das melhores cabeças deste país. Em 1912, Euclides da Cunha e Farias Brito participaram do concurso de cátedra para filosofia naquela instituição, sendo que o segundo acabou por ganhar após uma série de eventos que não nos cabe reportar aqui.

2 - Qual a função, a seu ver, do professor de Filosofia no segundo grau? O senhor acha que esta função deve ultrapassar a simples atividade docente?

$\mathrm{R}$ - Todos gostam de citar o conhecido truísmo: não se ensina filosofia, mas ensina-se a filosofar. Ao nosso entender, o professor de filosofia deve levar o aluno a refletir sobre questões fundamentais relativas ao conhecimento, à vida, à sociedade, ao relacionamento com o próximo, etc... Essa é a sua função específica, função que o professor desempenhará também informando o aluno sobre as grandes tentativas de solução destas questões, feitas no pass̊ado. Surge aí um lugar para a história da filosofia e para a leitura dos textos. Entendemos que o professor de filosofia é um docente como outro qualquer. Cada professor deve introduzir o aluno num mundo de pensamento, levando-o a refletir sobre certos problemas específicos. Não nos parece que o docente deva ultrapassar esses limites.

* Universidade de Brasília - Coordenador Nacional da Volta da Filosofia para o Segundo Grau - 70.910 - Brasília, DF.

Entrevistadores: João de Fernandes Teixeira e Maria Eunice Quilici Gonzales - Departamento de Filosofia - Faculdade de Educação, Ciências Sociais e da Documentação - UNESP - 17.500 - Marília - SP. 
3 - Qual é, a seu ver, o conteúdo ideal de um curso de Filosofia no segundo grau?

R - Preferimos não falar de um programa nacional e uniforme. Importante é que se ensine filosofia. Infelizmente, em certos círculos, há a tendência de se doutrinar o aluno, a nível de religião e/ou política partidária, a pretexto de levá-lo a pensar. Cremos que um curso de filosofia não pode ignorar a epistemologia, a lógica, os problemas ontológico-existenciais e éticos, mas com dosagens diferentes, de acordo com a formação do professor, as condições e o interesse do aluno, da área em que vive este, etc... etc... É óbvio que o religioso e o político devem ser objeto de reflexão, num curso de filosofia. Mas, reflexão não é doutrinação.

4 - Como o senhor vê a relação entre o ensino atual nas graduações e o ensino que idealmente esperamos para o segundo grau?

$\mathrm{R}$ - Que o ensino secundário brasileiro está falido é de conhecimento de todos. Num sistema de ensino mais aceitável, a filosofia deve ser uma matéria entre outras, sem qualquer pretensão de privilégio. Ao lado do matemático, do professor de português, do historiador, etc..., o filósofo é um dentre aqueles que formam a inteligência e o caráter do aluno.

$\mathrm{O}$ atual ensino superior de graduação em filosofia é precário. Temos que reconhecer isso e dizê-lo publicamente. Poucos são os doutores trabalhando nesse nível e a produção intelectual (livros, artigos etc...) é aí quase nula, se exceptuarmos sobretudo a USP. Os departamentos de filosofia têm que reconhecer, humildemente, esse fato, tentando melhorar o seu padrão de ensino e pesquisa. Sem uma boa graduação em filosofia, não haverá ensino decente dessa matéria, no segundo grau.

5 - Qual é a seu ver a carga horária de ensino de Filosofia que deve ser atribuída ao segundo grau? Em que séries es- taria melhor situado o ensino de Filosofia?

$R$ - Dois anos de filosofia, no segundo grau, com quatro horas-aula semanais seria a dose ideal. Obviamente, temos que admitir, nesse ponto, variações para mais ou menos, consoante circunstâncias e interesses regionais.

6 - Como se daria a reintrodução da Filosofia no segundo grau? Deveria ser um processo lento, iniciando-se nos grandes centros onde já existe maior número de graduações em funcionamento?

R - S. Paulo, Rio de Janeiro, Minas Gerais e Rio Grande do Sul poderiam dar o exemplo. Nesses estados, com certeza, há condições para a reintrodução geral e imediata da filosofia no segundo grau. Em estados como Santa Catarina, Paraná e Espírito Santo, a reintrodução poderia ser feita em tempo relativamente curto, enquanto nas demais unidades da federação alguns anos far-se-iam necessários até que se formassem professores em número suficiente para assumir todas as classes. Fundamental em tudo isso é a boa vontade das autoridades federais. Se elas quiserem iniciar o processo, este poderá ser levado adiante de modo satisfatório.

7 - Como o senhor vê a tentativa de reintrodução da Filosofia no segundo grau no Estado de S. Paulo? O que o senhor achou da idéia de ef etuar as "recomendações" aos Colégios da rede oficial de ensino paulista como foi propalado pela Secretaria de Educação do Estado de S. Paulo?

R - Essa história de "recomendações" de nada adianta. A disciplina deve ser reintroduzida através de uma decisão das autoridades, após um debate público que, aliás, já está acontecendo. Deixar o assunto a critério de cada diretor de colégio é, na prática, manter a situação atual, com variações insignificantes.

8 - Como o senhor vê outras tentativas de reintrodução da Filosofia no segundo grau? Refiro-me aos projetos dos depu- 
tados Fogaça e Bragato. O senhor não acha que isso poderia levar a alocação de mão-de-obra não especializada? Refiro-me a advogados, padres e outros que eventualmente seriam contratados para cobrir uma possível deficiência de licenciados em Filosofia, uma vez implantada a disciplina através de decretos.

R - Não conhecemos esses projetos. De qualquer maneira, os departamentos de filosofia vêm insistindo, nos seus três encontros (Rio, Gioânia e Santos), na necessidade de que a disciplina venha a ser oferecida por professores licenciados na área em questão. Colocar gente de outros ramos a ensinar filosofia seria um desastre, por razões óbvias. Cada macaco no seu galho. 9 - O que o senhor acha de afirmações de jornais de grande circulação de que o reforço de outras disciplinas tais como a língua portuguesa deveriam ter prioridade nas preocupações educacionais, deixando a filosofia para um segundo momento?

$\mathrm{R}$ - A língua portuguesa está representada em todas as séries de ensino de primeiro e segundo graus. Não cremos que a filosofia viesse a prejudicá-la. Ao contrário: uma das coisas que um bom ensino filosófico faz é levar o aluno a expressar-se com mais exa- tidão e clareza. Com isso, indiretamente, o ensino de línguas, em geral, é beneficiado.

10 - Quem seriam os "inimigos" da reintrodução da Filosofia no segundo grau? Como o senhor classifica afirmações tais como "a filosofia no segundo grau serviria apenas como instrumento de doutrinação, para a rapaziada do MR-8 infiltrada no ensino médio"reproduzida no seu artigo da Folha, em 9/9?

R - "Inimigos" da reintrodução da filosofia no segundo grau são todos aqueles que temem o pensamento. Aí se incluem tanto aquilo que os espanhóis chamam de "Bunker", em oposição à "direita civilizada", quanto a esquerda desvairada que faz e continuará a fazer do ensino uma tribuna de doutrinação. Ortega y Gasset disse que vivemos entre paralíticos e epilépticos. De um lado, a paralisia da direita, de outro, a epilepsia da esquerda. Entre esses extremos, nós gostaríamos de ver a saúde da discussão racional de problemas, discussão essa que o ensino filosófico ajuda a tornar possível. Sendo reintroduzida a filosofia no segundo grau, Bunker e MR-8 usa-la-ão para doutrinar, como já usam hoje história e os estudos sociais. Esperamos, entretanto, que esses fanáticos sejam e continuem a sér uma minoria. Sem esse postulado, é difícil crer no futuro do Brasil. 